\title{
Effect of lime, zinc and boron on yield and uptake of micronutrients by soybean
}

\section{P.K. RATHOD, V.G. SALVI, S.S. PAWAR AND K.N. CHAVAN}

Received : 18.09.2016; Revised : 21.10.2016; Accepted : 16.11.2016

MEMBERS OF RESEARCH FORUM:

Corresponding author :

P.K. RATHOD, Department of Soil Science and Agricultural Chemistry, College of Agriculture, (Dr.BSKKV)

Dapoli, RATNAGIRI (M.S.) INDIA
Co-authors :

V.G. SALVI, S.S. PAWAR AND K.N. CHAVAN, Department of Soil Science and Agricultural Chemistry, College of Agriculture, (Dr.BSKKV) Dapoli, RATNAGIRI (M.S.) INDIA

\section{Summary}

In order to study the effect of lime zinc and boron on soybean yield and uptake of micronutrients, a field experiment was conducted at Botany Farm, College of Agriculture, Dapoli, dist. Ratnagiri, in Konkan region of Maharashtra. The experiment was laidout in Randomized Block Design with three replications and the treatments included two levels of liming i.e. $1 / 2$ L.R. and 1 L.R in combination with soil and foliar application of $\mathrm{Zn}$ and $\mathrm{B}$ in combinations. The results of the experiment showed that the grain $\left(25.52 \mathrm{q} \mathrm{ha}^{-1}\right)$ and straw $\left(37.29 \mathrm{q} \mathrm{ha}^{-1}\right)$ yield of soybean was significantly increased due to application of $1 \mathrm{LR}+\mathrm{Zn}+$ $\mathrm{B}$ through soil and foliar spray along with RDF. The application of RDF + 1 LR + Zn and B through soil and foliar spray showed maximum uptake of zinc $\left(260.10 \mathrm{~g} \mathrm{ha}^{-1}\right)$ by grain and $\left(375.65 \mathrm{~g} \mathrm{ha}^{-1}\right)$ by straw. While the uptake of boron was significantly higher (75.51 and 105.31 $\mathrm{g} \mathrm{ha}^{-1}$ ) in grain and straw, respectively due to application of RDF $+1 / 2 \mathrm{LR}+\mathrm{B}$ through soil and foliar spray. The uptake of $\mathrm{Cu}, \mathrm{Fe}$ and $\mathrm{Mn}$ was significantly higher in treatment consisting $\mathrm{RDF}+1 / 2 \mathrm{LR}+\mathrm{B}$ through soil and foliar spray $\left(\mathrm{T}_{7}\right)$. At the same time, there was decrease in the uptake values of $\mathrm{Cu}, \mathrm{Fe}$ and $\mathrm{Mn}$ when lime dose was increased from $1 / 2 \mathrm{LR}$ to $1 \mathrm{LR}$ The uptake of micronutrients by soybean was favourably improved by application of boron $+1 / 2 \mathrm{LR}$ along with RDF.

Key words : Lime, Zinc, Boron, Soybean, Yield, Micronutrient uptake

How to cite this article : Rathod, P.K., Salvi, V.G., Pawar, S.S. and Chavan, K.N.(2016). Effect of lime, zinc and boron on yield and uptake of micronutrients by soybean. Asian J. Soil Sci., 11 (2) : 290-296 : DOI : 10.15740/HAS/AJSS/11.2/290-296. 